\title{
Long-term recovery of soft-bottom benthos following urban and industrial sewage treatment in the Nervión estuary (southern Bay of Biscay)
}

\author{
Ángel Borja*, Iñigo Muxika, Javier Franco \\ AZTI-Tecnalia Foundation, Marine Research Division, Portualdea, Herrera Kaia, s/n 20110 Pasaia, Spain
}

\begin{abstract}
The monitoring of marine benthic communities is based upon their ability to integrate long-term environmental conditions and it is considered an efficient, accurate and useful tool in the detection of pollution effects. However, long-term studies are scarce, and only few are devoted to recovery processes in estuaries following water treatment. In this contribution, the response of the Nervión estuary to sewerage processes is studied, using a long-term (1989 to 2003) data set of physico-chemical (dissolved oxygen, redox potential, organic matter, metals) and biological (density, richness and diversity in benthic communities) variables. The AMBI (AZTI's Marine Biotic Index) was designed to investigate the response of soft-bottom communities to natural and human-induced changes in European coastal water quality and is evaluated here. The first factor controlling the Nervión's benthic structure is found to be the bottom water oxygen saturation, hypoxia- and/or anoxia-produced azoic sediments. When water treatment commenced, benthic recolonisation was very rapid in terms of opportunistic species settlement. However, the community structure was highly disturbed, in terms of density, richness, diversity and AMBI values. AMBI and diversity values are highly correlated with oxygen saturation. When the water treatment continued, the high metal concentrations in the sediments inhibited recovery in some areas; they were a secondary factor in determining benthic structure. This contribution demonstrates that the AMBI is an efficient tool for detecting changes in benthic communities and in systems associated with sewerage schemes; it provides an indication of the proportions of opportunistic and sensitive species within a long-term series.
\end{abstract}

KEY WORDS: Benthic recovery $\cdot$ Water treatment $\cdot$ AMBI $\cdot$ Dissolved oxygen $\cdot$ Metals $\cdot$ Estuary Resale or republication not permitted without written consent of the publisher

\section{INTRODUCTION}

Biological monitoring is a useful tool for the evaluation of recovery processes in estuarine and marine environments and is a necessary part of environmental management. The monitoring of marine benthic communities is based conceptually upon their ability to integrate long-term environmental conditions at a particular site (Bilyard 1987, Warwick 1993). The use of both the community (as an indicator of the level of biological organisation) and the benthos (as an indicator of the biotic component) in monitoring programmes has been justified largely for temperate coastal areas (Clarke \& Green 1988, Warwick 1993, Clarke \& Warwick 1994, Eriksson et al. 2002). Long-term monitoring of benthic communities is considered an efficient, accurate and useful tool in the detection of pollution effects (Kröncke 1995, Brown \& Shillabeer 1997, Currie \& Parry 1999). However, long-term studies are scarce, and only sometimes are they devoted to recovery processes in estuaries (Shillabeer \& Tapp 1989, Tapp et al. 1993, Dauer \& Alden 1995, Attrill 1998, Wilson et al. 1998, Beukema et al. 1999, Hawkins et al. 2002, Llansó et al. 2004).

According to Spellerberg (1995), there is a clear and urgent need for the development of rigorous biological monitoring techniques, as well as some careful consideration to the logistics of such monitoring programmes. Therefore, the basic aspects to be considered in monitoring programmes are the requirements for studies previ- 
ous to the disturbance, i.e. before the commencement of human activities (such as in the case of dumping, enabling the application of corrective action), as well as the need to establish controls. When planning a monitoring survey of the benthos, several decisions have first to be taken, such as the sampling methodology; the derived measurable attributes of the organisms and the criteria and levels of organism discrimination groupings for the littoral zone under study (Warwick 1993).

In this way, and in recent years, the interest in benthic indicators has increased dramatically, with a long list of new indicators proposed (see Diaz et al. 2004 for a review). One of these indicators, the AMBI (AZTI's Marine Biotic Index), was designed to establish the ecological quality of European coasts, investigating the response of soft-bottom communities to natural and human-induced changes in water quality (Borja et al. 2000, 2003, 2004a). Hence, the AMBI offers a 'pollution/disturbance classification' of a particular site, representing the benthic community 'health' (sensu Grall \& Glémarec 1997). The AMBI is based upon wellknown ecological models (Glémarec \& Hily 1981, Hily 1984); its theoretical basis is that of the ecological adaptative strategies of $\mathrm{r}, \mathrm{k}$ and $\mathrm{T}$ (McArthur \& Wilson 1967, Pianka 1970, Gray 1979) and ecological succession in stressed environments (Bellan 1967, Pearson \& Rosenberg 1978).

The AMBI has been verified successfully in relation to a very large set of environmental impact sources, including drill cutting discharges, submarine outfalls, harbour and dyke construction, heavy-metal inputs, eutrophication, engineering works, diffuse pollutant inputs, dredging processes, mud disposal, sand extraction, oil spills and fish farming (Muxika et al. 2005). The geographical areas where it has been applied extend to the Atlantic Sea, Baltic Sea, Mediterranean Sea, North Sea and Norwegian Sea, all in Europe; also in Hong Kong, Uruguay and Brazil (Muniz et al. 2005, Muxika et al. 2005). The AMBI has been proposed also to be used, together with other structural parameters, for the assessment of the ecological status of estuarine and coastal waters, according to the requirements of the European Water Framework Directive (Borja et al. 2004c,d).

The Basque Country is located in the innermost part of the Bay of Biscay in northern Spain (Fig. 1). This region has a long history of industrialisation, especially in the Nervión estuary, which encompasses the large commercial port of Bilbao (Fig. 1). The estuary is $22 \mathrm{~km}$ long and is formed by the tidal part of the Nervión River. The natural features of the estuary have been modified dramatically by urban, industrial and port settlements, which have occupied practically the whole of the valley during the last 150 yr (Cearreta et al. 2004). The original estuary has been reduced rapidly in size through land reclamation to form a tidal channel (average dimensions: $100 \mathrm{~m}$ wide, $<10 \mathrm{~m}$ deep) completed in 1885 (Junta de Obras del Puerto 1910).

Exploitation of abundant local iron ore led, in the mid-19th century, to the early industrial development of the area together with an increase in the density of the population (around 2250 inhabitants $\mathrm{km}^{-2}$ and a total current population of 1000000 ) (Belzunce et al. 2004a). As a consequence, the estuary has received, over the last $150 \mathrm{yr}$, wastes from many sources (mineral sluicing, industrial wastes and urban effluents), which have significantly degraded its environmental quality (Belzunce et al. 2001, 2004a,b). Hence, the estuary received (before treatment in 1984) some $250000 \mathrm{~m}^{3}$ $\mathrm{d}^{-1}$ of urban wastewaters and $67000 \mathrm{~m}^{3} \mathrm{~d}^{-1}$ of industrial waters (produced mainly by the chemical, ironsteel and paper sectors), highly charged with toxic products (cyanide, heavy metals, fluorides and phenols) (Azkona et al. 1984). This produced extremely low concentrations of dissolved oxygen in the waters

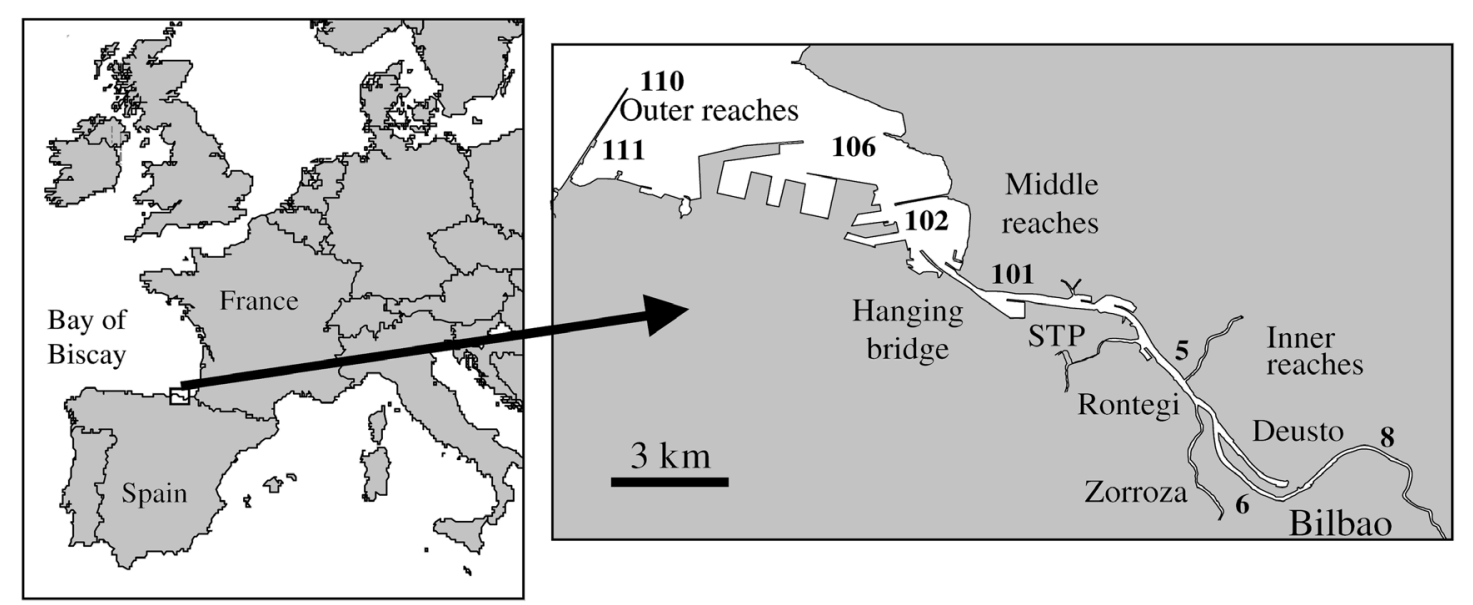

Fig. 1. Geographical location of Nervión estuary, within Bay of Biscay and northern Spain, showing sampling stations and main locations mentioned in text. STP = sewage treatment plant discharge at Galindo 
and a high content of organic matter and heavy metals in the sediments (Belzunce et al. 2001, 2004b, Landajo et al. 2004).

These discharges led to a deterioration in the softand hard-bottom benthic communities (Gorostiaga et al. 2004). The results obtained from an initial survey (Rallo et al. 1988) revealed that the main feature underlying the spatial distribution patterns of benthic communities was a stress gradient from the open coast towards the pollution source (the Nervión River).

Consequently, in 1979, in order to reverse this situation of poor environmental quality, a sewerage scheme for the area was approved by the Consorcio de Aguas Bilbao-Bizkaia (henceforth Consorcio); this is the local authority responsible for water supply and wastewater treatment. The diversion of outfalls began in the late 1980s, and the 'clean-up' of water began in 1991 with physico-chemical treatment (Franco et al. 2004); in 1995, the company causing most of the pollution in the estuary (the iron and steel company Altos Hornos de Vizcaya) was closed, and in 2001 a biological treatment plant came into operation. In 2002, the scheme covered around 700000 inhabitants and will be concluded in 2005 (Franco et al. 2004).

To survey the estuarine quality over time, a monitoring programme (including physico-chemical water and sediment parameters and the soft-bottom benthic, zooplanktonic and fish community composition of the estuary) has been carried out since 1989 by the Consorcio (Franco et al. 2002).

Hence, using this data set, the objectives of this contribution are to determine (1) the main physicochemical variables controlling the benthic distribution within the Nervión estuary and the structural parameters of the community, at a spatial level; (2) the long-term time course and recovery of benthic communities following water treatment; and (3) the ability of the AMBI to detect the recovery of benthic communities in polluted systems under the impact of sewerage schemes.

\section{MATERIALS AND METHODS}

Sampling. A network of monitoring stations along the Nervión estuary, from the inner to the outer reaches, was established by the Consorcio; this provides water, sediment and biological quality information from 8 subtidal sampling stations (Fig. 1). Stns 8, 6 and 5 are located along the inner reaches in a water depth of 8 to $10 \mathrm{~m}$; Stns 101 and 102 along the middle reaches in 10 to $15 \mathrm{~m}$ water depth; and Stns 106, 110 and 111 along the outer reaches in 25 to $30 \mathrm{~m}$ water depth. The benthic sampling was carried out every October from 1989 to 2003. At each of these stations, 2 replicates of benthos were collected using a Day grab $\left(0.1 \mathrm{~m}^{2}\right)$. The samples were sieved immediately following collection using a sieve with a mesh size of $1 \mathrm{~mm}$ and fixed in a solution of $4 \%$ formalin stained with rose Bengal (Holme \& McIntyre 1971).

Sediment data. At each station, a third grab was taken for sediment analysis (redox potential, organic matter content and metals). The redox potential was measured, immediately after placing the sample on board the survey vessel, with an Orion 977800 platinum electrode; this was connected to a Crison $501 \mathrm{pH}$ meter-millivoltmeter. The electrode was inserted some $5 \mathrm{~cm}$ into the sediment directly without disturbing the sample within the grab.

A $200 \mathrm{~g}$ sediment sample was dried at $80^{\circ} \mathrm{C}$ for $24 \mathrm{~h}$; it was then washed with freshwater on a sieve mesh of $63 \mu \mathrm{m}$. The dried residue was sieved on a column of 8 sieves $(4 \mathrm{~mm}$ to $31 \mu \mathrm{m})$. The percentages of gravel, sand and mud were calculated as $>2 \mathrm{~mm}$ fraction, $63 \mu \mathrm{m}$ to $2 \mathrm{~mm}$ and $<63 \mu \mathrm{m}$, respectively (Holme \& McIntyre 1971). The organic matter content was calculated using the 'loss on ignition' method (Kristensen \& Anderson 1993).

Metal concentrations $(\mathrm{Cd}, \mathrm{Cu}, \mathrm{Cr}, \mathrm{Hg}, \mathrm{Pb}, \mathrm{Zn})$ were analysed on the $<63 \mu \mathrm{m}$ size fraction, taken from the upper $10 \mathrm{~cm}$ sediment layer. Measurements were obtained using atomic absorption, using flame, graphite furnace and cold vapour techniques. The analytical procedure was checked against reference materials.

Water quality data. The mean bottom water temperature (used in the determination of oxygen saturation), together with its salinity and oxygen concentrations, was measured using conductivity and membrane polarographic probes, respectively. Between 8 and 12 surveys were undertaken every year. Mean oxygen values were derived on the basis of a 12 mo sampling period (from October of one year to September of the next year); these were used to establish the influence of oxygen on the benthic communities, as sampled in October.

Biological data. Identification was undertaken in the laboratory by means of a binocular microscope $(4 \times$ to $40 \times$ ). After computing the mean density of each taxon, at each sampling station the macrobenthic community structure was described by calculating the following descriptors (Washington 1984): richness (number of identified taxa), density ( $\mathrm{N}$ : ind $\mathrm{m}^{-2}$ ) and numerical diversity (Shannon Wiener $\mathrm{H}_{\mathrm{n}}^{\prime}$ : bits ind. ${ }^{-1}$ ).

Soft-bottom macrobenthic communities respond to environmental stress by means of different strategies (Bellan 1967). The AMBI was used here as an index of the disturbance of the benthic community (Borja et al. 2000), as has been demonstrated broadly elsewhere (Borja et al. 2003, Muniz et al. 2005, Muxika et al. 2005). The AMBI is based upon the proportions of 5 ecological groups (EG) to which the benthic species 
Table 1. Minima, maxima, mean and standard deviation (SD) of mud-clay fraction, redox potential and organic matter in sediments, together with metal concentration $\left(\mathrm{mg} \mathrm{kg}^{-1}\right.$, in dry wt) recorded in fine-grained fraction $(<63 \mu \mathrm{m})$ sediments of Nervión estuary. Data were collected between 1989 and 2003; zonation is defined in Fig. 1

\begin{tabular}{|c|c|c|c|c|c|c|c|c|}
\hline \multirow{4}{*}{$\begin{array}{l}\text { Mud: silt-clay (\% } \\
\text { Min - Max }\end{array}$} & \multirow{2}{*}{111} & \multirow{2}{*}{$\begin{array}{c}\text { Outer reaches } \\
110\end{array}$} & \multirow{2}{*}{$\overline{106}$} & \multicolumn{2}{|c|}{ — Middle reaches } & \multirow[b]{2}{*}{5} & \multirow{2}{*}{$\begin{array}{c}\text { Inner reaches } \\
6\end{array}$} & \multirow[b]{2}{*}{8} \\
\hline & & & & 102 & 101 & & & \\
\hline & & & & & & & & \\
\hline & $2.4-95.3$ & $46-99.2$ & $1.1-99.7$ & $2-88.6$ & $7-88.5$ & $11.7-97.4$ & $8.4-95.5$ & $2.1-96.5$ \\
\hline Mean $\pm \mathrm{SD}$ & $54.5 \pm 34.2$ & $91.7 \pm 14.7$ & $26.2 \pm 24.7$ & $38.6 \pm 31.1$ & $52.4 \pm 25.6$ & $73.2 \pm 22.4$ & $65.6 \pm 28.7$ & $58.8 \pm 35.2$ \\
\hline \multicolumn{9}{|c|}{ Redox potential } \\
\hline Min - Max & $-250-164$ & $-490-185$ & $-260-167$ & $-330-260$ & $-600-10$ & $-460-5$ & $-529-2$ & $-555-70$ \\
\hline Mean \pm SD & $-85 \pm 149.4$ & $-142 \pm 160.9$ & $-29 \pm 133.2$ & $-65 \pm 184.4$ & $-211 \pm 160.1$ & $-285 \pm 121.5$ & $-318 \pm 127.3$ & $-292 \pm 181.4$ \\
\hline \multicolumn{9}{|c|}{ Organic matter $(\%)$} \\
\hline Min - Max & $1.0-10.1$ & $5.1-11.6$ & $1.4-11.0$ & $2.2-10.2$ & $2.9-10.0$ & $4.1-25.3$ & $1.5-19.4$ & $2.4-19.9$ \\
\hline Mean \pm SD & $5.6 \pm 3.2$ & $8.8 \pm 1.8$ & $3.3 \pm 2.4$ & $6.1 \pm 2.8$ & $6.8 \pm 1.8$ & $10.2 \pm 4.9$ & $9.6 \pm 4.4$ & $10.7 \pm 5.0$ \\
\hline \multicolumn{9}{|c|}{ Cadmium (mg kg-1) } \\
\hline Min - Max & $0.8-4$ & $0.5-6$ & $0.3-4.8$ & $1.0-15.8$ & $1.0-23$ & $2.6-27$ & $2.8-10.8$ & $1.0-19$ \\
\hline Mean \pm SD & $2.2 \pm 1.2$ & $2.3 \pm 1.5$ & $2.3 \pm 1.3$ & $4.7 \pm 3.6$ & $8.4 \pm 5.8$ & $10.0 \pm 6.7$ & $5.4 \pm 2.4$ & $5.6 \pm 5.5$ \\
\hline \multicolumn{9}{|c|}{ Chromium (mg kg $\left.{ }^{-1}\right)$} \\
\hline Min - Max & $7-75.2$ & $23-78.1$ & $14-120$ & $26-130$ & $48-135.7$ & $14.4-189$ & $37-171$ & $48.4-786$ \\
\hline Mean \pm SD & $44.9 \pm 19.1$ & $50.7 \pm 12.5$ & $47 \pm 28.8$ & $76.2 \pm 29.3$ & $97.1 \pm 23.5$ & $101 \pm 51.6$ & $99.5 \pm 32.2$ & $207.7 \pm 233$ \\
\hline \multicolumn{9}{|c|}{ Copper $\left(\mathrm{mg} \mathrm{kg}^{-1}\right)$} \\
\hline Min - Max & $44-356$ & $58-195.3$ & $38.9-221$ & $68.2-345$ & $71-726.7$ & $70-585$ & $77-282.2$ & $66.7-478$ \\
\hline Mean \pm SD & $128 \pm 90.2$ & $117.5 \pm 46.6$ & $86.9 \pm 48.3$ & $150.5 \pm 78.4$ & $237.2 \pm 183.6$ & $219.4 \pm 157.8$ & $135.7 \pm 52$ & $200.8 \pm 144.6$ \\
\hline \multicolumn{9}{|c|}{ Mercury $\left(\mathbf{m g ~ k g}^{-1}\right)$} \\
\hline Min - Max & $0.59-9.5$ & $0.6-7.6$ & $0.85-9$ & $0.99-10.6$ & $0.89-9.3$ & $0.12-27.7$ & $0.24-7$ & $0.38-4.75$ \\
\hline Mean \pm SD & $4.06 \pm 2.94$ & $3.3 \pm 2.15$ & $2.62 \pm 2.21$ & $3.88 \pm 2.88$ & $3.74 \pm 2.64$ & $7.91 \pm 9.35$ & $2.6 \pm 2.36$ & $1.91 \pm 1.3$ \\
\hline \multicolumn{9}{|c|}{ Lead $\left(\mathrm{mg} \mathrm{kg}^{-1}\right)$} \\
\hline Min - Max & $65-803$ & $61-596$ & $78-216$ & $92-768$ & $83-1221$ & $107-2263$ & $112-442$ & $60-377$ \\
\hline Mean \pm SD & $272.9 \pm 217.8$ & $291.9 \pm 153$ & $134.7 \pm 49.6$ & $246.8 \pm 181$ & $377.2 \pm 307$ & $459.9 \pm 552.5$ & $194 \pm 91.2$ & $191.9 \pm 108.8$ \\
\hline \multicolumn{9}{|c|}{ Zinc $\left(\mathbf{m g ~ k g} \mathbf{~ g}^{-1}\right)$} \\
\hline Min - Max & $204-1120$ & $311-732$ & $198-680$ & $302-1360$ & $360-1948$ & $294-1965$ & $375-1797$ & $384-3708$ \\
\hline Mean \pm SD & $503.5 \pm 295.3$ & $466.1 \pm 150.6$ & $328.3 \pm 135.7$ & $618.7 \pm 297.8$ & $878.5 \pm 494.1$ & $975.3 \pm 542.1$ & $716.9 \pm 326.3$ & $1163.8 \pm 974.3$ \\
\hline
\end{tabular}

are allocated (based upon Leppäkoski 1975, Glémarec \& Hily 1981, Grall \& Glémarec 1997): EG I, disturbance-sensitive species; EG II, disturbance-indifferent species; EG III, disturbance-tolerant species; EG IV, second-order opportunistic species; and EG V, firstorder opportunistic species (Borja et al. 2000).

The corresponding AMBI values were calculated using software freely available at www.azti.es (AMBI v.2.0); this includes the EG of 2805 taxa, updated in September 2004. The AMBI was calculated for each of the replicates and then averaged for the entire station, as recommended by Borja et al. (2004c) and in the guidelines for the index (Borja \& Muxika 2005).

The disturbance assessment was undertaken according to the thresholds established on a scale of 0 to 7 for the AMBI based upon the proportions between the various ecological groups: 0 to $\leq 1.2$ values, corresponding to undisturbed communities; 1.2 to $\leq 3.3$, slightly disturbed; 3.3 to $\leq 5$, moderately disturbed; 5 to $\leq 6$, heavily disturbed; and 6 to 7 , extremely disturbed (for details of the scale, see Borja et al. 2000, Muxika et al. 2005). These thresholds are coincident with the benthic community health proposed by Grall \& Glémarec (1997).

Statistical treatment of data. To assess how well the benthic community structure was correlated with abiotic variables, a pair-wise Pearson's correlation between variables was carried out. Correlations with $\mathrm{p}<$ 0.001 were considered significant.

A principal component analysis (PCA) was applied to the data set of 10 abiotic variables and 4 biological variables for 8 sampling locations and over $15 \mathrm{yr}$ (Zitko 1994). Normal distribution of the data was achieved using a $\log (1+x)$ transformation standardised by subtracting the mean and dividing by the standard deviation.

Afterwards, a canonical correspondence analysis (CCA) was carried out by means of the CANOCO package (ter Braak \& Šmilauer 1998); this used 4 biological variables, 9 environmental variables (mud percentage, organic matter content, redox potential and metals [Cd, Cr, Cu, Hg, Pb, Zn]) and a covariable (oxygen saturation). Hill's scaling was used, focused on the inter-sample distances, with data being log-transformed $(\log [1+x])$. 


\section{RESULTS}

The bed of most of the locations within the Nervión estuary consist of mud or sandy-mud sediments (Table 1). The redox potential reaches lower values in the inner parts (with means around -300) than in the outer estuary (means ca. -50 , except at the very muddy Stn 110) (Table 1). The organic matter tends to decrease from the inner to the outer reaches, both in terms of mean and maximum values, from $>10 \%$ to around 5\%, except at Stn 110 (Table 1).

The highest mean metal values are reached in the innermost part of the estuary ( $\mathrm{Cr}$ and $\mathrm{Zn}$, at $\mathrm{Stn}$ 8) or in the area between Stns 5 and $101(\mathrm{Cd}, \mathrm{Cu}, \mathrm{Hg}, \mathrm{Pb})$. The same pattern is shown in the maximum values (Table 1). In some cases $(\mathrm{Hg}, \mathrm{Pb})$, high mean values are found in the outer reaches (Stn 111) (Table 1). Overall, the mean and maximum concentrations of all the metals analysed can be considered very high.

Similarly, the bottom salinity values are very high, with means over the whole period of $28.7 \pm 4.2$ (SD) at Stn 8 to $31.3 \pm 1.8$ (Stn 6), $32.8 \pm 1.4(\operatorname{Stn} 5), 34.4 \pm 0.7$ (Stn 101), and $>35 \pm 0.5$ at the remaining stations.

The inner estuary shows the effect of the sewage treatment process in terms of oxygen saturation recovery in the bottom water layers (Fig. 2). Hence, without treatment (1989-1990), the mean oxygen bottom values, for the whole data set representative of Stns 8, 6 and 5 , were $<22 \%$.

When the physico-chemical water treatment started in the estuary in 1991, the mean oxygen values reached nearly $40 \%$; they maintained this level until the company causing most of the pollution closed in 1995. At this time, the oxygen levels were over $40 \%$. After the commencement of biological treatment in 2001 the oxygen values increased progressively, reaching a mean of almost $70 \%$ in 2003. The middle and outer reaches of the estuary show the same pattern, where the mean values increased from 70 to $80 \%$ in 1990 to 90 to $100 \%$ in the $2000 \mathrm{~s}$.

Bottom waters in the inner estuary were hypoxic (or anoxic, at the beginning of the time series) most of the time, especially in spring and summer (only a single taxon was identified at Stn 8 , in 2001). The presence of fauna has become permanent from Stn 5 seawards; this is the zone where the bottom waters rarely present hypoxia (Fig. 2). Hence at Stn 5, the number of taxa has varied between 2 and 22 during the last $15 \mathrm{yr}$, with a mean value of ca. 8. The total density has varied between 30 and 26600 ind. $\mathrm{m}^{-2}$, with the benthic com- munities being dominated by annelids. The opportunistic and moderately hypoxia-resistant polychaete Capitella capitata was normally the dominant species at Stns 5 and 101. Other common taxa in this area are the extremely hypoxia-resistant Malacoceros fuliginosus, oligochaetes and the gastropod Hydrobia ulvae. However, in recent years new components of the Scrobicularia plana-Cerastoderma edule community (characteristic of estuaries in the Basque Country; see Borja et al. 2004b), such as the polychaetes Hediste diversicolor, Streblospio shrubsolii and Heteromastus filiformis, the crustaceans Cyathura carinata, Carcinus maenas and Corophium sp., or the molluscs Tapes decussata or C. edule, have colonised this 'unbalanced' area (sensu Bellan 1967 and Grall \& Glémarec 1997).

Over the middle reaches of the estuary (Stns 101 \& 102), the taxa are those of the Abra alba community in the Basque Country (Borja et al. 2004b): A. alba, A. prismatica, Corbula gibba, Thyasira flexuosa, Lagis (=Pectinaria) koreni, Mysella bidentata, Cerianthus membranaceus, Polydora polybranchia, Euclymene oerstedi, Mediomastus fragilis, Melinna palmata, etc.; and several species that indicate pollution, such as Capitella capitata, Malacoceros fuliginosus, Pseudopolydora paucibranchiata, etc.

The outer reaches (Stns 106, 110 and 111) are occupied by a transition between the Tellina tenuis Lusitanian-boreal community and the Venus fasciata community, called here the 'Tellina-Venus community' (Borja et al. 2004b). The identified species correspond to both communities, such as Nephtys cirrosa, N. hombergii, Tellina fabula, T. tenuis, Spiophanes bombyx, Gouldia minima, Nucula sulcata, Dentalium dentalis, Echinocardium cordatum, Dispio uncinata, Cumopsis fagei, Diogenes pugilator, Venus fasciata, V. casina, Chame-

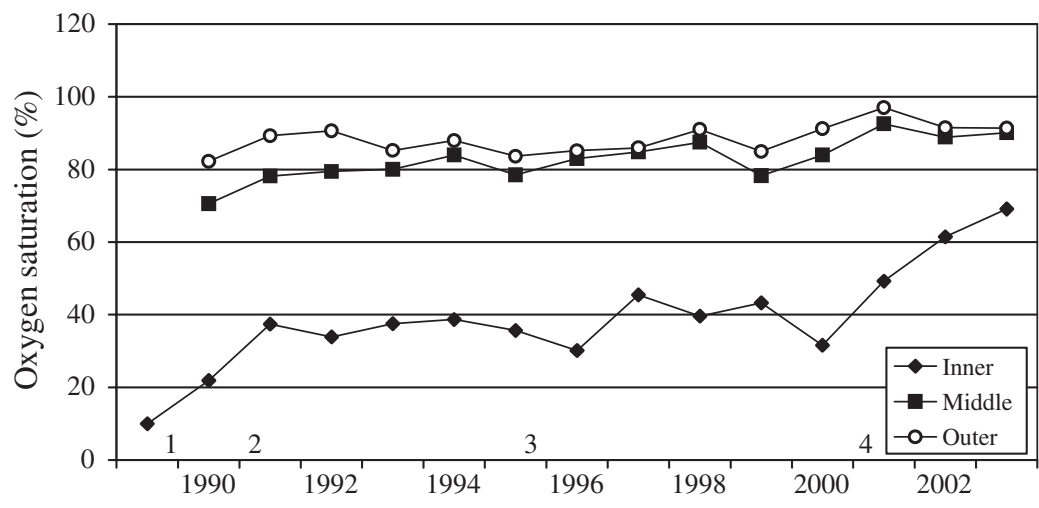

Fig. 2. Time course of mean oxygen saturation (\%) values for period 1989 to 2003 within various reaches in Nervión estuary (Fig. 1). Means are derived on the basis of 8 to 12 annual values. Numbers = years in which (1) no water treatment existed in estuary, (2) physico-chemical water treatment started, (3) company causing most pollution in estuary closed, and (4) biological water treatment started. For station locations, see Fig. 1 

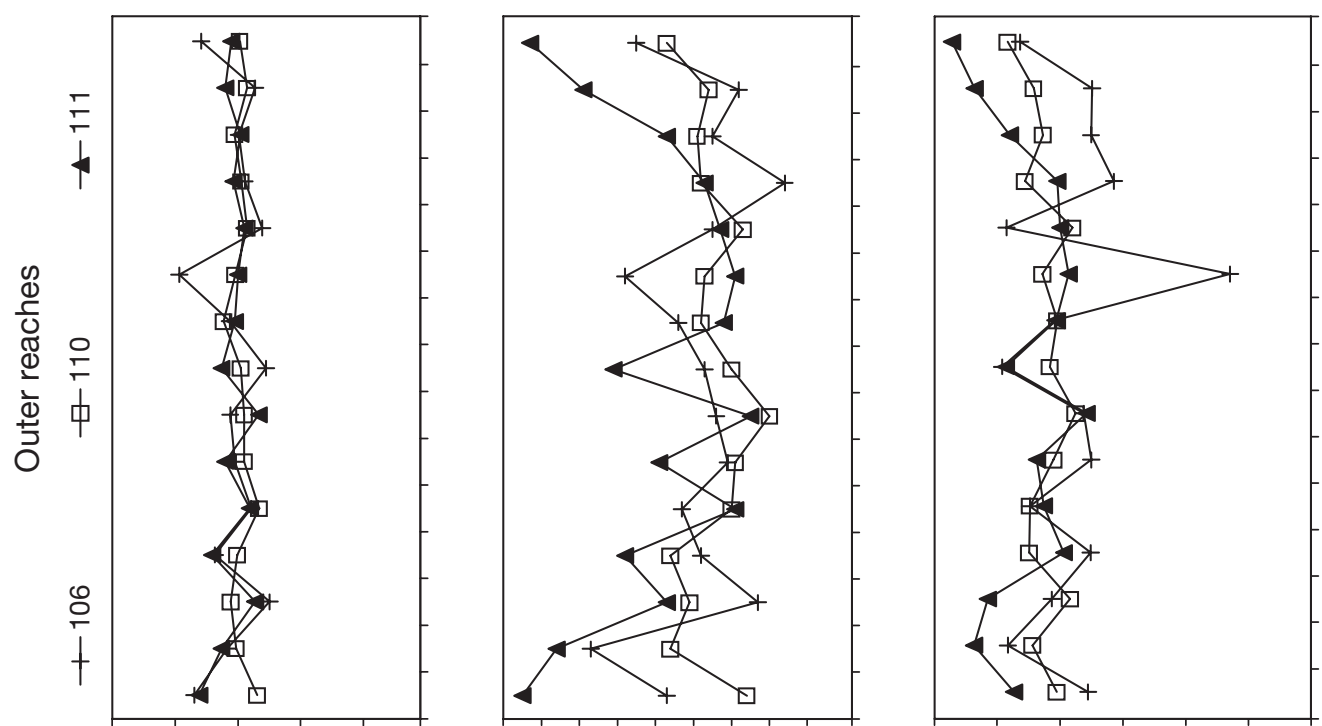

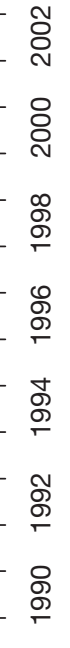
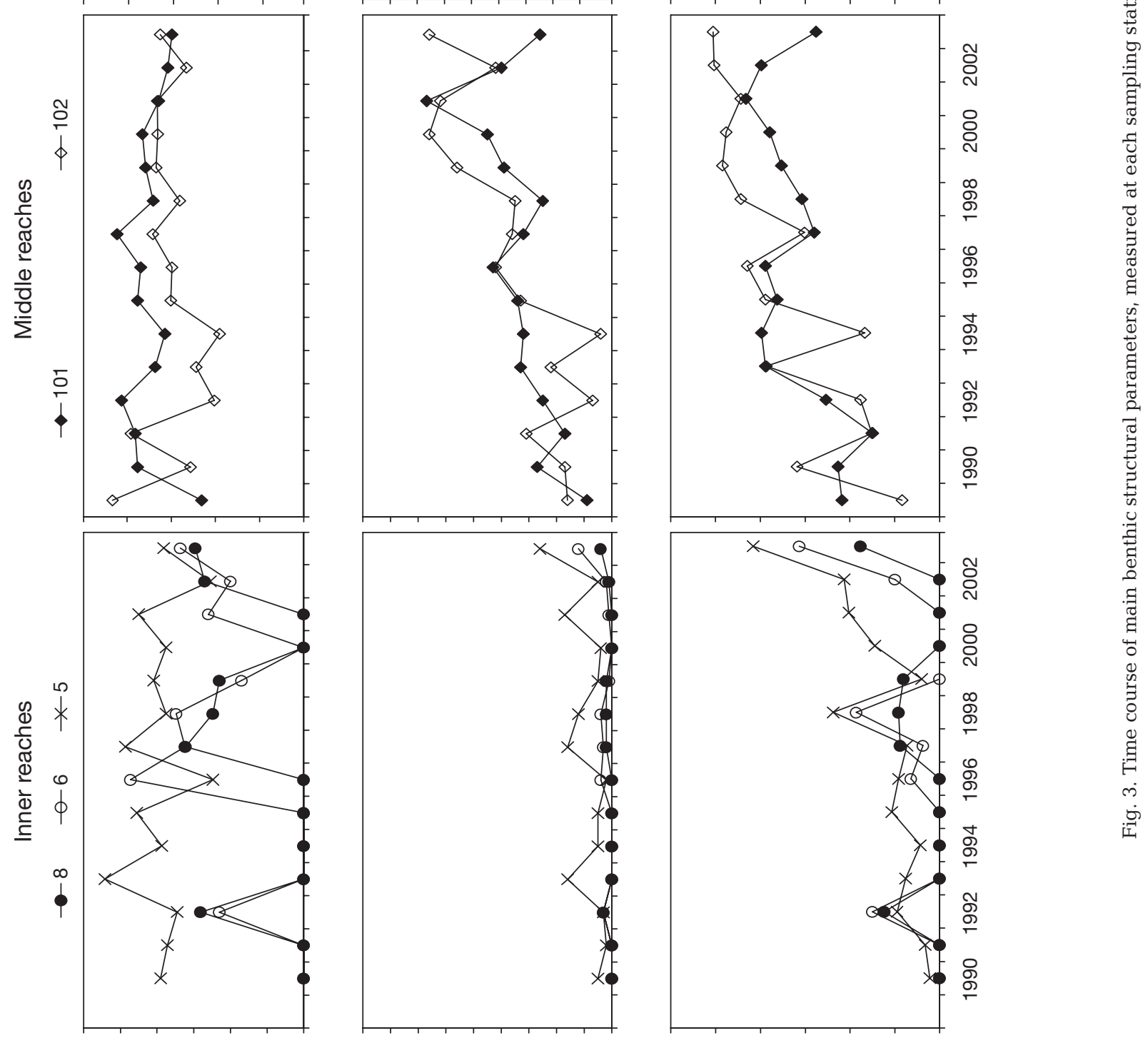

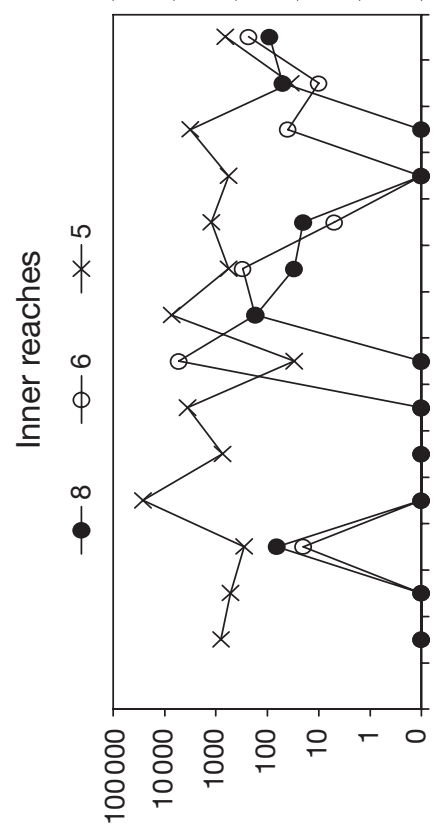

Density (ind. $\mathrm{m}^{-2}$ )

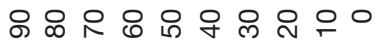

Taxonomic richness ( $N$ taxa)

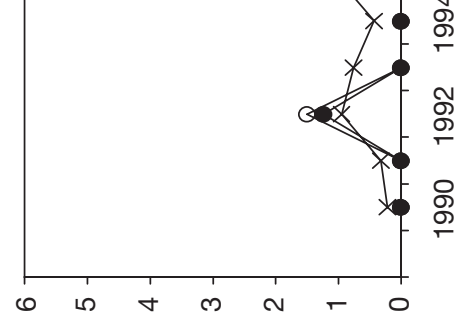

Diversity $\left(\mathrm{H}^{\prime}\right)\left(\right.$ bit ind. $\left.{ }^{-1}\right)$ 


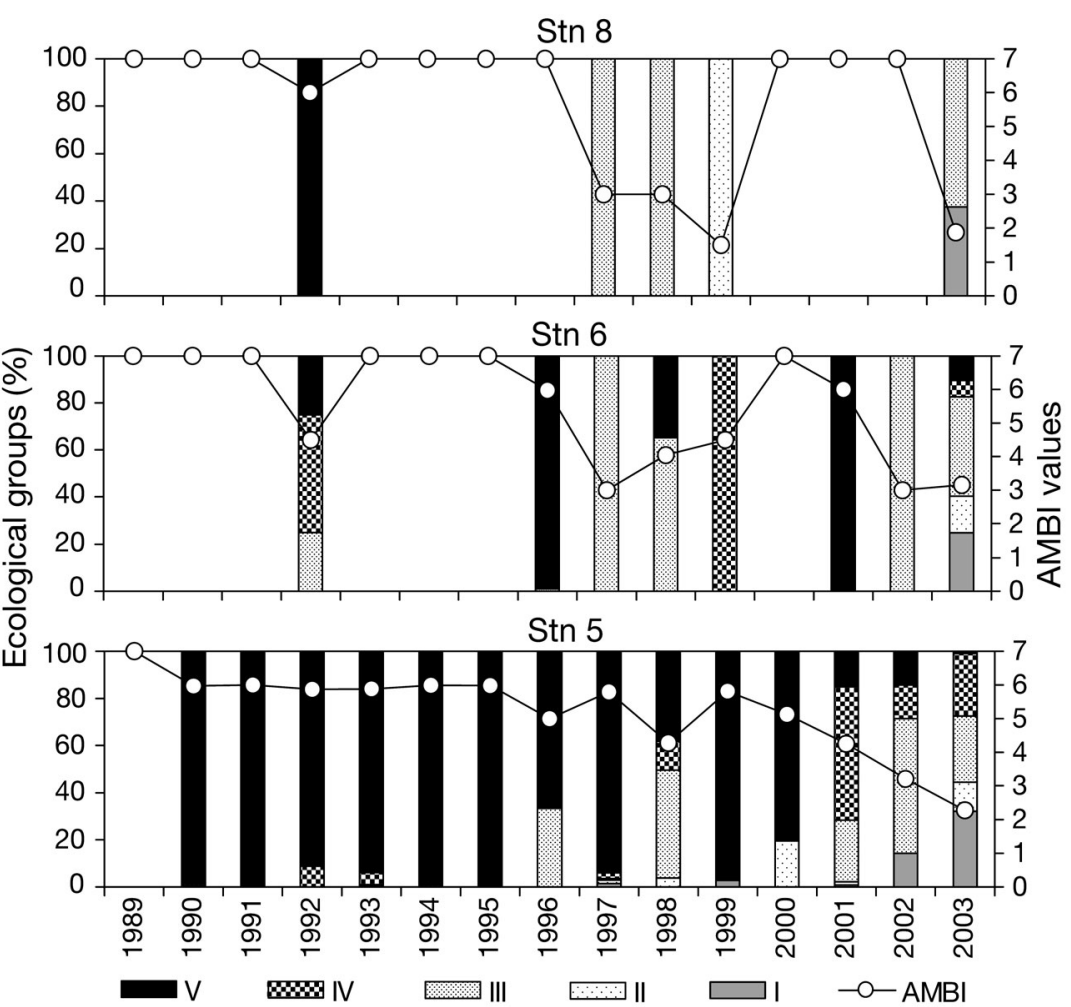

Fig. 4. Time course of proportion of ecological groups and AMBI values, at each sampling station within inner reaches (for locations, see Fig. 1)

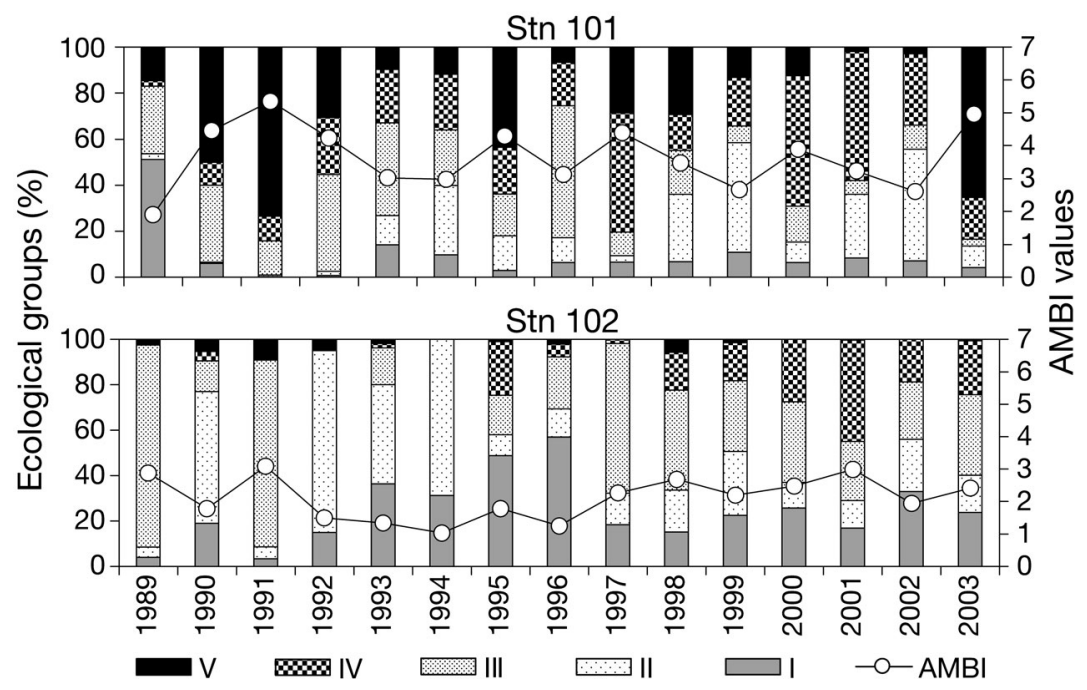

Fig. 5. Time course of proportion of ecological groups and AMBI values, at each sampling station within middle reaches (for locations, see Fig. 1)

between the inner channel and the outer reaches, with no clear time-series trends (Fig. 3). The 2 innermost stations (8 and 6) were azoic, or very impoverished, throughout most of the time series. Fauna have been found only during 8 of the past $15 \mathrm{yr}$ (mainly during the last years of the time series), although the number of taxa has never been greater than 10 (the highest value reached, in 2003). The number of taxa increased over the middle reaches (Stns 101 and 102) throughout the time series, from 10 to 15 taxa in 1989 to a mean of 60 in 2000 to 2003 . There is no clear trend in the results obtained for the outer reaches, with mean values of ca. 50 taxa (Fig. 3).

The inner estuary has improved progressively, in terms of its AMBI values, from an azoic situation (Stns 8 and 6), to a moderately disturbed pattern (Figs. 4, 5 \& 6). However, 3 'anomalous' AMBI values $(<3)$, in terms of progressive improvement, were obtained for Stn 8 in 1997, 1998 and 1999 (Fig. 4). At Stns 6 and 5, the initial community was dominated by EG V (opportunistic), and in recent years, EG III and IV have become dominant (Fig. 4). Even within the outer estuary, the AMBI has decreased, with sensitive (EG I) and indifferent (EG II) species becoming increasingly abundant (Fig. 6).

When studying the entire data set, the AMBI presents a highly significant negative correlation with oxygen saturation $(\mathrm{r}=-0.9)$, diversity $(\mathrm{r}=-0.86)$, richness $(\mathrm{r}=-0.72)$ and redox potential $(\mathrm{r}=-0.57)$; it shows a highly significant positive correlation with organic matter $(\mathrm{r}=0.5), \mathrm{Cd}(\mathrm{r}=0.45), \mathrm{Cr}(\mathrm{r}=0.47)$ and $\mathrm{Zn}(\mathrm{r}=0.49)$ (Table 2$)$. The same pattern is shown by other structural parameters, such as richness and diversity, but not by density (Table 2).

Bottom oxygen saturation explains $81 \%$ of the variability in the AMBI values (Fig. 7), corresponding to the high-

lea striatula, Urothoe brevicornis, Bathyporeia elegans, Prionospio steenstrupi, Branchiostoma lanceolatum, Spisula subtruncata, etc.

The distribution of benthic communities in the Nervión estuary consists of (1) a general increase in the number of taxa and diversity, both seawards and throughout the time series; and (2) a maximum density at the boundary est value in the correlation matrix (Table 2). Taking into account the high number of low oxygen values and the azoic situations at Stns 8 and 6, the latter were removed from the correlation analysis in order to enable examination of different patterns. The result is that the AMBI maintains the same pattern of correlation with the structural parameters (but with lower correlation val- 

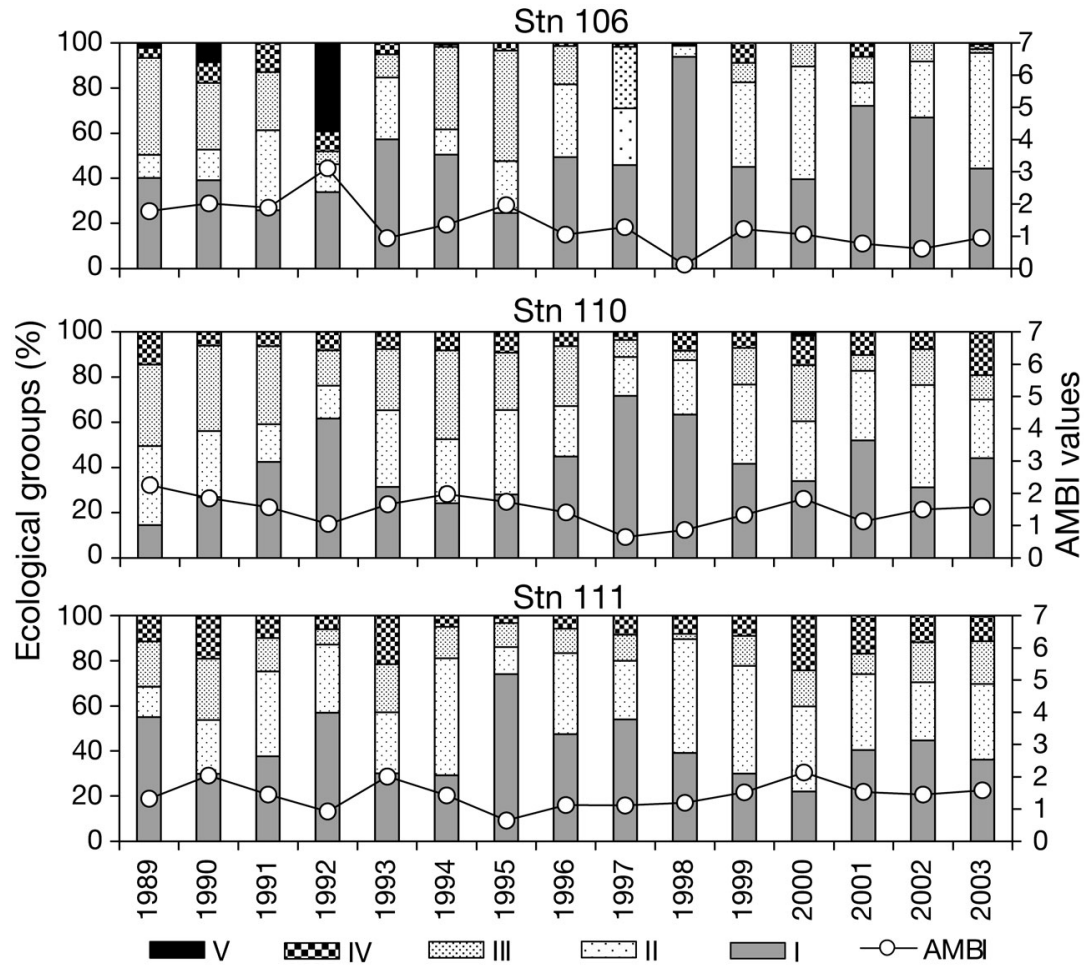
sampling station within outer reaches (for locations, see Fig. 1)

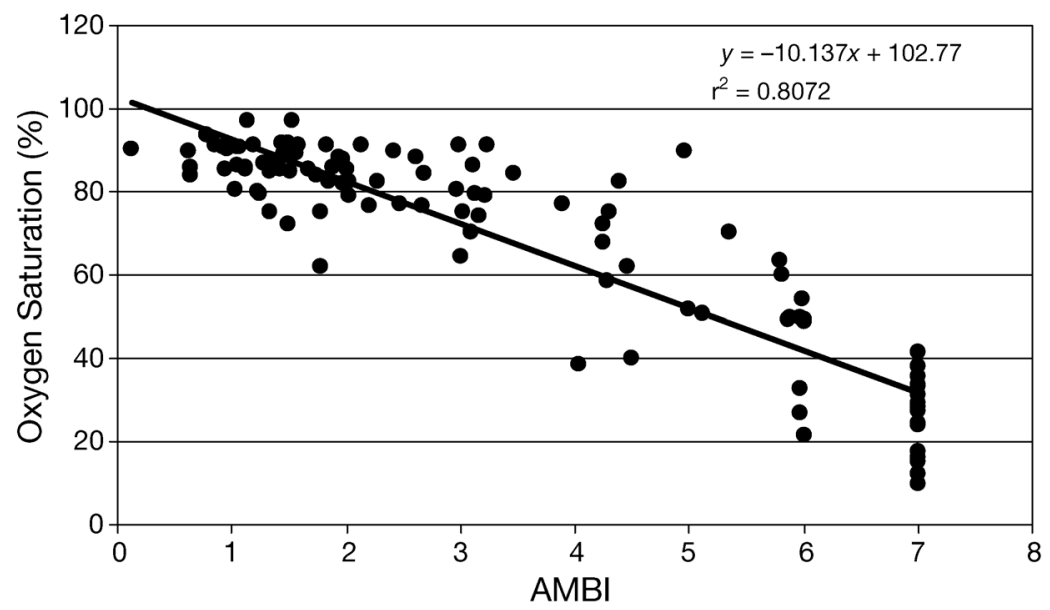

Fig. 7. Regression between AMBI and oxygen saturation, including data from all stations and years
Fig. 6. Time course of proportion of ecological groups and AMBI values, at each

AMBI correlated significantly with all of the metals (Table 2). The same pattern is shown by the diversity but, in this particular case, maintaining the correlation with oxygen saturation (Table 2).

The first 3 components of the PCA explain $>79 \%$ of the total variability in the system. The first component shows a clear relationship with the structural parameters and oxygen (Fig. 8a), both in terms of oxygen saturation in the bottom waters and the redox potential of the sediments, and explains $46 \%$ of the variance. Hence, the higher the saturation and redox potential, the greater the diversity and richness and the lower the AMBI values (i.e. more sensitive species) in the communities. This gradient clearly separates stations from the inner and outer reaches of the estuary (Fig. 8a). The second component appears to be related to the sediment metal concentrations, and explains $21.7 \%$ of the variance. However, the metals are also related to biotic variables (Fig. 8b). Hence, the more metals, the higher the AMBI values (opportunistic species) and the lower the diversity and richness. The third component is related to sediment characteristics (mud and organic matter content) (Fig. 8b), and explains $14.3 \%$ of the variance.

Taking into account that oxygen saturation explains most of the benthic communities' variability, it was used as covariable in a CCA to analyse the effect of the remaining abiotic parameters. In this case, only $\mathrm{Cu}$ and $\mathrm{Cd}$ were significant in the analysis $(\mathrm{p}<0.05)$. The biotic-abiotic parameter correlations were 0.388 for the first axis and 0.364 for the second. Both axes together explained $14.8 \%$ of the variance in the biotic data.

\section{DISCUSSION}

ues), except in the case of oxygen saturation, which is not now correlated (Table 2). This pattern can be explained by the break in the relationship around the limit between AMBI values determining slightly and moderately disturbed habitats $(\mathrm{AMBI}=3.3)$. Thus, $97 \%$ of samples with AMBI values <3.3 had an oxygen saturation of $>70 \%$; conversely, only $16 \%$ of stations with an AMBI value of $>3.3$ had an oxygen saturation of $>70 \%$ (Fig. 7). In contrast, the correlation with the metal concentrations increased in all cases, with the
In the Nervión estuary, the high amounts of organic matter discharged into the estuary throughout the 20th century has resulted in extended periods of hypoxia; this has even led to anoxia in the inner reaches. Oxygen deficiency is one of the most important factors leading to stress in aquatic organisms (Llansó 1992); as such, it is perhaps the most widespread anthropogenically induced deleterious effect in the marine environ- 


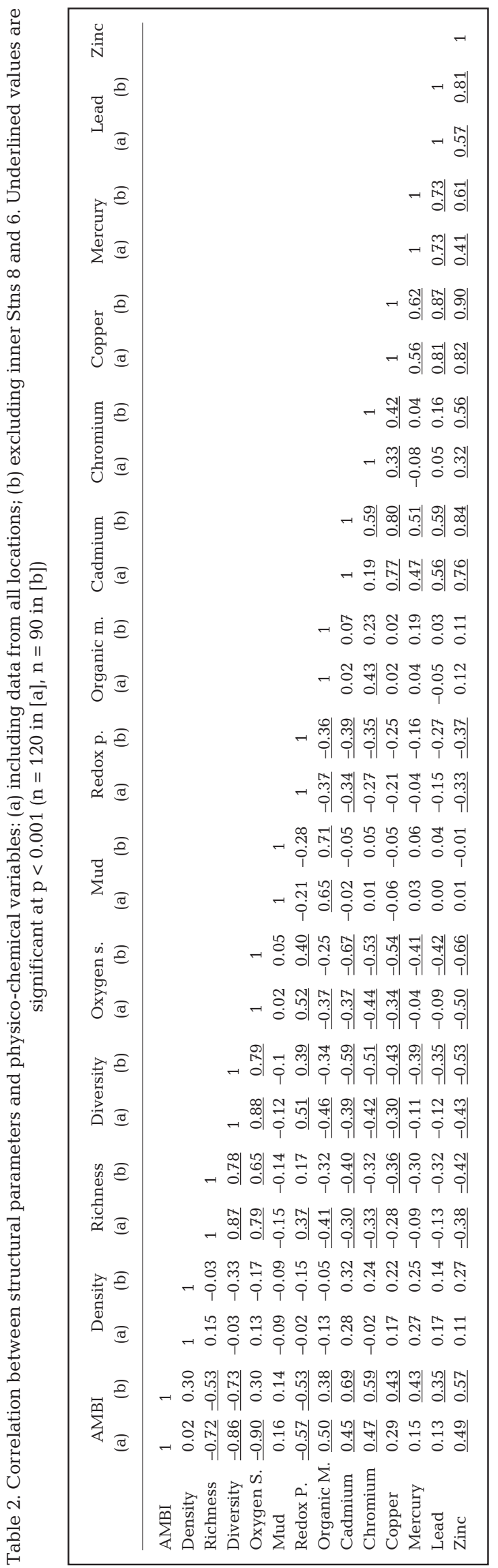

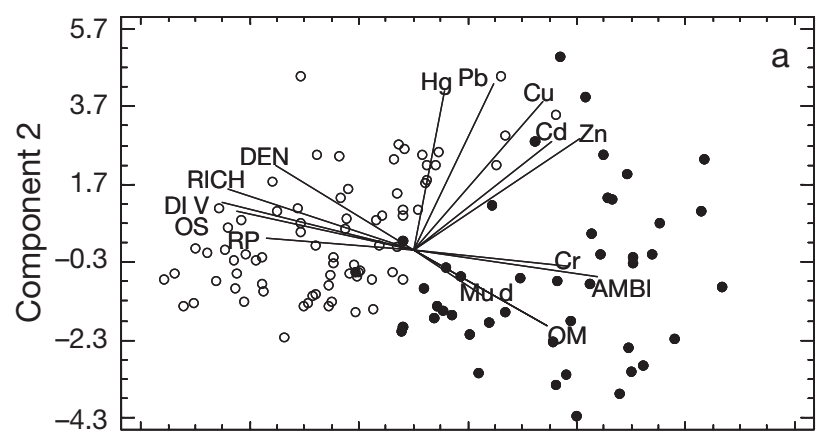

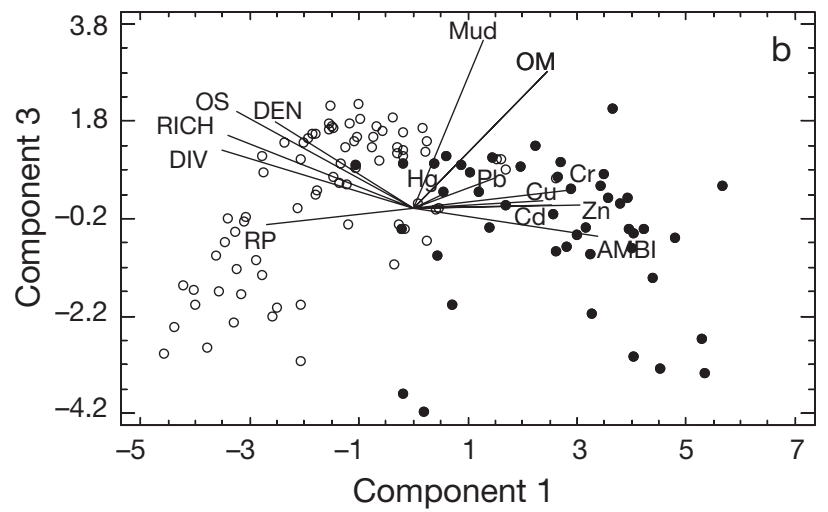

Fig. 8. Principal component analysis, including both biologi$\mathrm{cal}$ and physico-chemical variables. (a) Comparison between Components 1 and 2; (b) comparison between Components 1 and 3. DEN = density; $\mathrm{RICH}=$ richness; DIV = diversity; OS = oxygen saturation; $\mathrm{RP}=$ redox potential $; \mathrm{OM}=$ organic matter. Others are metals, mud and AMBI. $\bullet=$ inner reaches (Stns 8, 6 and 5); $\mathrm{O}=$ middle and outer reaches (for locations, see Fig. 1)

ment, causing localised mortality of benthic macrofauna (Diaz \& Rosenberg 1995).

The hypoxia causes adverse effects on the benthic macrofauna, such as (1) mortality, (2) changes in behaviour, (3) reductions in growth, (4) decreases in biomass and diversity and (5) changes in the density and species composition of benthic assemblages (Diaz \& Rosenberg 1995). Most of these effects have been detected in the Nervión estuary. Hypoxia usually increases the density of small, short-lived species (opportunistic species: EG IV \& V, sensu Borja et al. 2000); it decreases the density of large, long-lived species (sensitive species: EG I \& II) (Holland et al. 1987, Llansó 1992, Llansó et al. 2004). As a consequence, in hypoxic areas, assemblages of large infauna are usually of low diversity, density and biomass; assemblages of small infauna show higher density and biomass (Dauer et al. 1992, Diaz \& Rosenberg 1995). After extended hypoxic periods, these patterns have been detected in the inner reaches of the Nervión estuary. For example, for the period 1989 - 2003, the communities were dominated by opportunistic species and dramatic changes occurred in their structural parameters. 
In the middle reaches, with higher oxygen levels, the benthic communities show an equilibrium between opportunistic and sensitive species groups, together with higher structural values.

Oxygen has been proposed by González-Oreja \& Sáiz-Salinas (1998) as the key environmental factor explaining the distribution of benthos in the Nervión estuary. In order to predict the levels of macrozoobenthic biomass in the sediments of the Nervión estuary, González-Oreja \& Sáiz-Salinas $(1999,2003)$ undertook a short-term experimental study. These authors envisaged 3 recovery situations, or scenarios, relating to the water-quality objectives proposed by the local Water Authority (Consorcio 1993), with a level of dissolved oxygen in the waters of $60 \%$. From these oxygen values the predicted biomass of soft-bottom macrobenthic communities in the Nervión estuary should be ca. $1 / 10$ to $1 / 2$ of the value obtained for the mouth (Sáiz-Salinas \& González-Oreja 2000). Therefore, González-Oreja \& Sáiz-Salinas $(1999,2003)$ concluded that any factor raising oxygen levels in the water column of the Nervión estuary would enhance the total community biomass.

In the Nervión estuary, recolonisation of the inner reaches has taken place by species from the outer reaches, establishing a typical Scrobicularia-Cerastoderma community (sensu Borja et al. 2004b); increasing values of richness and diversity, with reducing density ranges, have occurred throughout the period from 1989 to 2003. Hence, it has taken $>13 \mathrm{yr}$ for the middle reaches to achieve the same richness and diversity that was present in 1989 in the outer reaches (Fig. 3). On the other hand, it has taken 14 to $15 \mathrm{yr}$ for the inner reaches to achieve the same state as that of the middle reaches, in 1989. The time course in the outer reaches appears to be influenced by other drivers, such as the North Atlantic Oscillation or precipitation (A. Borja et al. unpubl. data). This recolonisation pattern is very similar to that predicted experimentally for this estuary by GonzálezOreja \& Sáiz-Salinas (1999, 2003) and Sáiz-Salinas \& González-Oreja (2000).

Following hypoxia, the initial recovery of benthic communities usually follows the Pearson \& Rosenberg (1978) enrichment-disturbance model. This model is based on the AMBI response to impact sources (Borja et al. 2000, 2004c). Hence, the time course of AMBI values at stations most affected by water treatment in the Nervión estuary is related closely to the recovery of the oxygen saturation levels in the bottom water layers. The best example is Stn 5 (Fig. 4), in which anoxia led to azoic sediments prior to 1990 . The physico-chemical treatment increased oxygen saturation. The period 1990-1995 was dominated by opportunistic species, together with a highly disturbed community, in terms of AMBI. After closure of the company which caused most of the pollution in the area, the community evolved positively; this is by incorporating species from EG I-III. The associated AMBI values show a moderately to highly disturbed community. This pattern coincides with a new increase in oxygen saturation (Fig. 2). Finally, following the commencement of biological treatment and the high increase in oxygen saturation, a progressive improvement in AMBI values has been detected; there is dominance now of EG I-III. On the other hand, a small worsening has been detected at Stns 101 and 102, which are situated downstream of the sewage treatment plant discharge (Fig. 1); this itself has increased in its discharge volume throughout the period of investigation.

This response (of AMBI to oxygen depletion and recovery) has been detected by Muxika et al. (2005) in Norwegian hypoxic fjords. In these cases, the recovery of the affected communities, to a steady state community following the return to normoxic conditions, can take several years; this is as detected in the Nervión estuary. In this particular case, some 'anomalous' situations can be detected using AMBI, when low AMBI values are coincident with very few species $(<3)$ or individuals e.g. over 1997-1999 at Stn 8, where the AMBI values are lower than expected (Fig. 4). If the species are classified as EG I or EG II, the final AMBI value can be underestimated. It is recommended that such data be removed from the overall analysis (Borja et al. 2004c, Borja \& Muxika 2005).

Oxygen depletion and chemical pollutants are the main inhibitory environmental factors for soft-bottom macrozoobenthos in the Nervión estuary (Sáiz-Salinas 1997). Concern has been expressed locally over chemical pollutants within the sediments; these may act as a reservoir of contaminants in the future (Ruiz de la Rosa \& Sáiz-Salinas 1993). Anoxic conditions usually have the effect of binding some contaminants more tightly than for aerobic sediments (Riedel et al. 1999). Contaminants in contact with the oxic waters can be released back into solution (Calmano et al. 1993), causing toxic effects in the biota. For example, Trannum et al. (2004) have shown that high copper levels in sediments $(400$ to $1500 \mathrm{mg} \mathrm{kg}^{-1}$ ) had a distinct negative effect on benthic colonisation.

This process appears to occur in the Nervión estuary because some of the modifications in the middle reaches are related to high metal levels (both mean and maxima values), especially at Stns 5 and 101. The relative severity of sediment toxicity must be much lower than the oxygen deficiency effects, at least for the polychaete Nereis diversicolor, as detected by Sáiz-Salinas \& Francés (1997). However, for the period $1989-2003,72.6 \%$ of the total $\mathrm{Zn}$ samples analysed in the Nervión estuary, $38.5 \%$ of $\mathrm{Pb}, 13.7 \%$ of $\mathrm{Cd}$ and $13.3 \%$ of $\mathrm{Cu}$ are over the effect range 
median established by Long et al. (1995); this shows a decrease from between $35 \%(\mathrm{Cu})$ and $90 \%(\mathrm{Zn})$ for the period 1989-1991 to between $0 \%(\mathrm{Cu}, \mathrm{Cd})$ and $45 \%(\mathrm{Zn})$ for the period 2002-2003. This pattern indicates the potential toxic effect on the sediments throughout the period. Metal pollution in the estuary has decreased progressively since 1989 (Belzunce et al. 2004b), probably influencing the recovery of the benthic communities.

Sáiz-Salinas \& González Oreja (2000) have developed additional techniques to assess recovery using the estuarine bivalve Scrobicularia plana. This species is more sensitive to chemically contaminated sediments than Nereis diversicolor. Lack of concordance between the bivalve and the polychaete, as to which sediments were toxic, has indicated that each species responded differently.

The ecological implications of the experimental results obtained by Sáiz-Salinas \& González Oreja (2000), corroborated in situ in this contribution, are clear. Azoic sediments in the inner part of the estuary, independent of their chemical contamination, have been repopulated by species of the ScrobiculariaCerastoderma community, as predicted by Sáiz-Salinas \& González Oreja (2000). On the other hand, the results of the experimentation undertaken with Scrobicularia plana have demonstrated that chemical contamination in areas of the Nervión estuary has the potential to cause deleterious biological effects on indigenous benthic organisms. Based upon these recovery simulations, $S$. plana should provide valuable information within the context of an extensive toxicological assessment of contaminated sediments. This observation would facilitate the management implementation of the extremely costly remedial action plans to remove 'hot spots' of sediment contamination; otherwise, such hot spots could delay or impede faunal recovery once dissolved oxygen conditions in the estuary have improved (Sáiz-Salinas \& González Oreja 2000, González Oreja \& Sáiz-Salinas 2003, Gorostiaga et al. 2004).

The pattern of recolonisation described for the Nervión estuary is very similar to that detected in other estuaries, with the same problems of hypoxia and high contaminant levels (Shillabeer \& Tapp 1989, Tapp et al. 1993, Llansó et al. 2004); it follows, probably, the same repopulation mechanisms as described by Beukema et al. (1999). After the experience gained from other estuaries associated with gradual clean-up and de-industrialisation, such as the Mersey (Hawkins et al. 2002) where the recovery took more than $40 \mathrm{yr}$, and taking into account the time course in the inner reaches of the Nervión estuary, complete recovery of the entire estuary is likely to take place within the next 10 to $15 \mathrm{yr}$.

\section{CONCLUSIONS}

Few long-term studies have been undertaken on the effects of water treatment on soft-bottom benthic communities. In highly polluted systems, such as the Nervión estuary, the first factor driving the benthic community structure is the bottom water oxygen saturation; consequently, other associated factors, such as the redox potential in sediments or the hypoxia and/or anoxia, produce azoic sediments. When water treatment commences, benthic recolonisation is very rapid in terms of opportunistic species settlement. However, the community structure is highly disturbed in terms of density, richness, diversity and associated AMBI values. In these particular systems the AMBI and diversity are highly correlated with oxygen saturation. As water treatment continues, the high metal concentrations in the sediments can inhibit recovery in certain areas; they are a secondary factor in determining the benthic structure. Against this background, the AMBI can be an efficient tool in detecting changes in benthic communities in systems associated with sewerage schemes; it indicates the proportions between opportunistic and sensitive species in long-term series.

Acknowledgements. This study was supported by various contracts undertaken between the Consorcio de Aguas Bilbao-Bizkaia and AZTI. Some of the benthic groups were identified by INSUB. We thank Professor Michael Collins (School of Ocean and Earth Science, University of Southampton, UK) and Xabier Irigoien (AZTI) for kindly advising us on some details of the paper.

\section{LITERATURE CITED}

Attrill MJ (1998) A rehabilitated estuarine ecosystem. The environment and ecology of the Thames estuary. Kluwer, Dordrecht

Azkona A, Jenkins SH, Roberts HMG (1984) Sources of pollution of the estuary of the river Nervión, Spain - a case study. Water Sci Technol 16:95-125

Bellan G (1967) Pollution et peuplements benthiques sur substrat meuble dans la région de Marseille. 1 Partie. Le secteur de Cortiu. Rev Int Océan Med VI-VII: 53-87

Belzunce MJ, Solaun O, Franco J, Valencia V, Borja A (2001) Accumulation of organic matter, heavy metals and organic compounds in surface sediments along the Nervion estuary (Northern Spain). Mar Pollut Bull 42:1407-1411

Belzunce MJ, Solaun O, Valencia V, Pérez V (2004a) Contaminants in estuarine and coastal waters. In: Borja A, Collins $M$ (eds) Oceanography and marine environment of the Basque Country. Elsevier Oceanogr Ser 70:233-251

Belzunce MJ, Solaun O, González-Oreja JA, Millán E, Pérez V (2004b) Contaminants in sediments. In: Borja A, Collins $M$ (eds) Oceanography and marine environment of the Basque Country. Elsevier Oceanogr Ser 70:283-315

Beukema JJ, Flach EC, Dekker R, Starink M (1999) A longterm study of the recovery of the macrozoobenthos on large defaunated plots on a tidal flat in the Wadden Sea. J Sea Res 42:235-254 
Bilyard GR (1987) The value of benthic infauna in marine pollution monitoring studies. Mar Pollut Bull 18:581-585

Borja A, Muxika I (2005) Guidelines for the use of AMBI (AZTI's marine biotic index) in the assessment of the benthic ecological quality. Mar Pollut Bull 50:787-789

Borja Á, Franco J, Pérez V (2000) A marine biotic index to establish the ecological quality of soft-bottom benthos within European estuarine and coastal environments. Mar Pollut Bull 40(12):1100-1114

Borja Á, Muxika I, Franco J (2003) The application of a Marine Biotic Index to different impact sources affecting soft-bottom benthic communities along European coasts. Mar Pollut Bull 46:835-845

Borja A, Valencia V, Franco J, Muxika I, Bald J, Belzunce MJ, Solaun O (2004a) The water framework directive: water alone, or in association with sediment and biota, in determining quality standards? Mar Pollut Bull 49:8-11

Borja A, Aguirrezabalaga F, Martínez J, Sola JC, GarcíaArberas L, Gorostiaga JM (2004b) Benthic communities, biogeography and resources management. In: Borja A, Collins M (eds) Oceanography and marine environment of the Basque Country. Elsevier Oceanogr Ser 70:455-492

Borja A, Franco J, Muxika I (2004c) The Biotic Indices and the Water Framework Directive: the required consensus in the new benthic monitoring tools. Mar Pollut Bull 48(3-4): 405-408

Borja A, Franco J, Valencia V, Bald J, Muxika I, Belzunce MJ, Solaun O (2004d) Implementation of the European Water Framework Directive from the Basque Country (northern Spain): a methodological approach. Mar Pollut Bull 48(3-4):209-218

Brown AR, Shillabeer N (1997) Development of a biologically based environmental quality standard from a long-term benthic monitoring programme in the North Sea. Oceanol Acta 20:275-282

Calmano W, Hong J, Förstner U (1993) Binding and mobilization of heavy metals in contaminated sediments affected by $\mathrm{pH}$ and redox potential. Water Sci Technol 28:223-235.

Cearreta A, Irabien MJ, Pascual A (2004) Human activities along the Basque coast during the last two centuries: geological perspective of recent anthropogenic impact on the coast and its environmental consequences. In: Borja A, Collins M (eds) Oceanography and marine environment of the Basque Country. Elsevier Oceanogr Ser 70:27-50

Clarke KR, Green RH (1988) Statistical design and analysis for a 'biological effects' study. Mar Ecol Prog Ser 46: 213-226

Clarke KR, Warwick RM (1994) Change in marine communities: an approach to statistical analysis and interpretation. Natural Environment Research Council, UK

Consorcio (1993) Agiria 1992 Memoria. Consorcio de Aguas Bilbao-Bizkaia, Bilbao

Currie DR, Parry GD (1999) Changes to benthic communities over 20 years in Port Phillip Bay, Victoria, Australia. Mar Pollut Bull 38:36-43

Dauer DM, Alden RW (1995) Long-term trends in the macrobenthos and water quality of the lower Chesapeake Bay (1985-1991). Mar Pollut Bull 30:840-850

Dauer DM, Rodi AJ Jr, Ranasinghe JA (1992) Effects of low dissolved oxygen events on the macrobenthos of the lower Chesapeake Bay. Estuaries 15:384-391

Diaz RJ, Rosenberg R (1995) Marine benthic hypoxia: a review of its ecological effects and the behavioural responses of benthic macrofauna. Oceanogr Mar Biol Annu Rev 33:245-303

Diaz RJ, Solan M, Valente RM (2004) A review of approaches for classifying benthic habitats and evaluating habitat quality. J Environ Manage 73:165-181

Eriksson BK, Johansson G, Snoeijs P (2002) Long-term changes in the macroalgal vegetation of the inner Gullmar Fjord, Swedish Skagerrak coast. J Phycol 38: 284-296

Franco J, Aspillaga E, Muxika I, Pérez V, Solaun O, Borja A (2002) Hypoxia and anoxia in small temperate estuaries: patterns of oxygen deficiency, effects and recovery. In: Thurston RV (ed) Proc 6th Int Symp Fish Physiol, Toxicol \& Wat Qual. La Paz, BCS Mexico. EPA/600/R-02/097 (US): 79-94

Franco J, Borja A, Valencia V (2004) Overall assessmenthuman impacts and quality status. In: Borja A, Collins M (eds) Oceanography and marine environment of the Basque Country. Elsevier Oceanogr Ser 70:581-597

Glémarec M, Hily C (1981) Perturbations apportées à la macrofaune benthique de la baie de Concarneau par les effluents urbains et portuaires. Acta Oecol 2:139-150

González-Oreja JA, Sáiz-Salinas JI (1998) Exploring the relationships between abiotic variables and benthic community structure in a polluted estuarine system. Water Res 32: 3799-3807

González-Oreja JA, Sáiz-Salinas JI (1999) Fitting predictive models of the biological recovery in the Bilbao Estuary. Acta Oecol 20:471-477

González-Oreja JA, Sáiz Salinas JI (2003) Recovery simulations of grossly polluted sediments in the Bilbao estuary. Mar Pollut Bull 46:42-48

Gorostiaga JM, Borja A, Díez I, Francés G, Pagola-Carte S, Sáiz Salinas JI (2004) Recovery of benthic communities, in polluted systems. In: Borja A, Collins M (eds) Oceanography and marine environment of the Basque Country. Elsevier Oceanogr Ser 70:549-578

Grall J, Glémarec M (1997) Using biotic indices to estimate macrobenthic community perturbations in the Bay of Brest. Estuar Coast Shelf Sci 44(Suppl A):43-53

Gray JS (1979) Pollution-induced changes in populations. Phil Trans R Soc Lond Ser B 286:545-561

Hawkins SJ, Gibbs PE, Pope ND, Burt GR and 6 others (2002) Recovery of polluted ecosystems: the case for long-term studies. Mar Environ Res 54:215-222

Hily C (1984) Variabilité de la macrofaune benthique dans les milieux hypertrophiques de la Rade de Brest. Thèse de Doctorat d'Etat, Université Bretagne Occidentale. Vols 1 \& 2

Holland AF, Shaughnessy AT, Hiegel MH (1987) Long-term variation in mesohaline Chesapeake Bay macrobenthos: spatial and temporal patterns. Estuaries 10:370-378

Holme NA, McIntyre AD (1971) Methods for the study of marine benthos. Blackwell, Oxford

Junta de Obras del Puerto de Bilbao (1910) Churruca y el Puerto de Bilbao (Apuntes biográficos, Antecedentes históricos y Resumen descriptivo de las obras de mejora de la Ría y Puerto de Bilbao). Imprenta Emeterio Verdes, Bilbao, p 1-165

Kristensen E, Andersen FO (1993) Determination of organic carbon in marine sediments: a comparison of two CHNanalyzer methods. J Exp Mar Biol Ecol 109:15-23

Kröncke I (1995) Long-term changes in North Sea benthos. Senckenb Mar 26:73-80

Landajo A, Arana G, de Diego A, Etxebarria N, Zuloaga O, Amouroux D (2004) Analysis of heavy metal distribution in superficial estuarine sediments (estuary of Bilbao, Basque Country) by open-focused microwave-assisted extraction and ICP-OES. Chemosphere 56:1033-1041

Leppäkoski E (1975) Assessment of degree of pollution on the basis of macrozoobenthos in marine brackish-water envi- 
ronments. Acta Acad Aboensis Ser B 35(2):1-96

Llansó RJ (1992) Effects of hypoxia on estuarine benthos: the lower Rappahannock River (Chesapeake Bay), a case study. Estuar Coast Shelf Sci 35:491-515

Llansó RJ, Kelley FS, Scott LC (2004) Chesapeake Bay water quality monitoring program: Long-term benthic monitoring and assessment component, Level 1 Comprehensive Report (July 1984-December 2003). Prepared for the Maryland Department of Natural Resources by Versar, Columbia, MD

Long ER, MacDonald DD, Smith SL, Calder FD (1995) Incidence of adverse biological effects within ranges of chemical concentrations in marine and estuarine sediments. Environ Manage 19:81-97

McArthur RH, Wilson EO (1967) The theory of island biogeography. Princeton University Press, Princeton, NJ

Muniz P, Venturini N, Pires-Vanin AMS, Tommasi LR and Borja A (2005) Testing the applicability of a Marine Biotic Index (AMBI) for assessing the ecological quality of softbottom benthic communities in the South America Atlantic region. Mar Pollut Bull 50:624-637

Muxika I, Borja A, Bonne W (2005) The suitability of the marine biotic index (AMBI) to new impact sources along European coasts. Ecol Ind 5(1):19-31

Pearson TH, Rosenberg R (1978) Macrobenthic succession in relation to organic enrichment and pollution of the marine environment. Oceanogr Mar Biol Annu Rev 16:229-311

Pianka ER (1970) On r- and K- selection. Am Nat 104(940): 592-597

Rallo A, Gorostiaga JM, Sáiz-Salinas JI, Isasi I, Limia JM (1988) Comunidades bentónicas del Abra de Bilbao y su entorno (N. España). Cah Biol Mar 29:3-19

Riedel GF, Sanders JG, Osman RW (1999) Biogeochemical control on the flux of trace elements from estuarine sediments: effects of seasonal and short-term hypoxia. Mar Environ Res 47:349-372

Ruiz de la Rosa JM, Sáiz-Salinas JI (1993) Bioavailability of heavy metals in two estuaries of the Basque Country. Acta

Editorial responsibility: John Gray (Contributing Editor), Oslo, Norway
IIIe Col Int Océanogr Golfe Gascogne 111-116

Sáiz-Salinas JI (1997) Evaluation of adverse biological effects induced by pollution in the Bilbao Estuary. Environ Pollut 96:351-359

Sáiz-Salinas JI, Francés G (1997) Enhanced growth in juvenile Nereis diversicolor after its exposure to anaerobic polluted sediments. Mar Pollut Bull 34:437-442

Sáiz-Salinas JI, González-Oreja JA (2000) Stress in estuarine communities: lessons from the highly-impacted Bilbao estuary (Spain). J Aquat Ecosyst Stress Recov 7:43-55

Shillabeer N, Tapp JF (1989) Improvements in the benthic fauna of the Tees estuary after a period of reduced pollution loadings. Mar Pollut Bull 20(3):119-123

Spellerberg IF (1995) Monitoring Ecological Change. Cambridge University Press, Cambridge, UK

Tapp JF, Shillabeer N, Ashman CM (1993) Continued observations of the benthic fauna of the industrialised Tees estuary, 1979-1990. J Exp Mar Biol Ecol 172:67-80

ter Braak CJF, Šmilauer P (1998) CANOCO Reference Manual and User's Guide to Canoco for Windows. Software for Canonical Community Ordination (v.4). Centre for Biometry Wageningen (Wageningen, Netherlands) and Microcomputer Power (Ithaca, New York)

Trannum HC, Olsgard F, Skei JM, Indrehus J, Overas S, Eriksen J (2004) Effects of copper, cadmium and contaminated harbour sediments on recolonisation of soft-bottom communities. J Exp Mar Biol Ecol 310:87-114

Warwick RM (1993) Environmental impact studies on marine communities: pragmatical considerations. Austral J Ecol 18:63-80

Washington HG (1984) Diversity, biotic and similarity indices. A review with special relevance to aquatic ecosystems. Water Res 18:653-694

Wilson RS, Heislers S, Poore GCB (1998) Changes in benthic communities of Port Phillip Bay, Australia, between 1969 and 1995. Mar Freshw Res 49(8):847-861

Zitko V (1994) Principal component analysis in the evaluation of environmental data. Mar Pollut Bull 28:718-722

Submitted: February 3, 2005; Accepted: October 14, 2005

Proofs received from author(s): March 20, 2006 